\title{
Does Foreign Aid Contribute to HDI Improvement?
}

\author{
Jordan Signor $^{1}$ and Julien Vandernoot ${ }^{2}$
}

\begin{abstract}
Foreign aid is aimed at creating a favourable environment capable to foster economic growth and development in poorer countries. Accordingly, recipient countries might rely to a certain extent on external aid to attaint higher welfare levels. In principle, donour's aid-allocation preference, aided country policies, its institutional background, and economic environment are decisive in the aid effectiveness. Should not the previous conditions be met, could the country fall into the poverty trap. Contrary to a large strand of the literature measuring the role external funding has with regards to its contribution to welfare and growth, we show that Human Development Index is positively driven by internal factors, whilst foreign aid, and private funding have no significant effect. This is coherent with a more recent strand of the literature, suggesting that on average, aid is ineffective in recipient countries.
\end{abstract}

JEL classification numbers: F35, H20, H83, O1.

Keywords: Foreign Aid, HDI improvement, Developing Countries.

${ }^{1}$ Research and Teaching Assistant, Public Finance and Taxation Department, University of Mons, Belgium, Jordan.

2 Associate Professor, Public Finance and Taxation Department, University of Mons, Belgium.

Article Info: Received: February 3, 2021. Revised: February 20, 2021.

Published online: March 11, 2021. 


\section{Introduction}

Our aim here is to elaborate on how government policy decision can influence Human Development Index (HDI). We follow a large strand of the Public Economy field, and relate to the recent literature unravelling outer, and national interventions in terms of economic and social outcomes.

Relying on the World Bank dataset and on a sample of 163 countries over the period 1990-2018, we find that Official Development Aid, official assistance, and FDI have no significant beneficial effect on HDI measures. Whereas internal factors contribute to the same indicator such as an increase in education or government expenditures, gross capital formation, economic growth or a reduction in income inequality all consistently improve the HDI ranking.

\section{Theoretical background}

The last decades have seen official development aid (ODA), and foreign direct investment (FDI) scale in importance from developed countries, and new donors such as China (see World Bank Development Indicators database, and Strange et al., 2017). Be it in bilateral or multilateral inflow forms, measurement of aid effectiveness, and fungibility have been scrutinized, and the concept of "conditionality" has been extensively used in scientific literature as well as in international agencies (Svensson, 1999; Lessmann, and Markwardt, 2016).

Accordingly, we may consider aid as prevalent for development and economic growth in terms of needs and amount allocated (see Alesina, and Dollar, 2000; Chauvet, and Mesplé-Somps, 2007; or Tezanos et al., 2013).

However, development projects, and aid ineffectiveness have been brought to light. Foreign aid appears to be triggering inconsistent economic development and welfare improvement in recipient countries (Fleck, and Kilby, 2006; Wagner, 2014; Dreher et al., 2019; or Zardoub, and El Abed, 2019).

While many internal and external factors have been identified as explanatory for aid allocation, and effectiveness, we will restrain our scope of study on budgetary and fiscal issues. We categorize relevant factors in three categories: institutional quality, policy decisions, and economic conditions.

\subsection{Institutional quality}

Conceptually, "institution" refers to political institutions, specifically democracy and governance quality. Notably, institutions matter for aid allocation, its fungibility, and rent-seeking activities (Kanmas and Sarantides, 2016; Roessler, 2019).

In the Indian context, Prakash et al. (2019) emphasize the detrimental effects that incompetent and corrupted incumbents have in regions where failing or ineffective institutions (political and judicial) fail to enforce rigorous controls over officials.

Similarly, the absence of controls and conditionality give ground to rent seeking, and aid diversion to African leaders' families, and jurisdiction of birth or 
neighbouring regions of the Chinese aid allocation. This can be explained through the political survival approach; leaders adopt this behaviour on pure electoral and support-building purposes (Dreher et al., 2019).

On the donor side, Alesina and Dollar's (2000) seminal work showed how allocation choices differed based upon specific considerations; namely, democratic regimes mattered more to the United States, whereas Nordic countries relied more on democratic institutions. This "democratic preference" has, however, been contradicted by Alesina, and Weder (2002) - non-democratic regimes receive just as much aid.

Still in the United States, Fleck, and Kilby (2006) highlight how partisanship leads US aid allocation: Democrats have a democratic institution and needs-based approach, while Republicans are driven by mercantilist interests.

\subsection{Policy decisions}

Policy commitments and binding aid allocations would be key elements in understanding aid inflows, and their effective allocation (Svensson, 1999). Policy decisions on infrastructure and essential public goods provision would also be explanatory of economic gains.

In emerging democracies, redistributive fiscal policies can be used as a regime stabilizer to contain political unrest. Kanmas, and Sarantides (2016) add this institutional setting, which highlights that in this particular context, also characterized by poorly developed institutions, fiscal policies are used to reduce the Gini coefficient.

Subsequently in the development of recipient countries, institutions, policies, and legal controls guaranteeing law enforcement rules, economic openness or liberty become a prerequisite to attract FDI as well as achieve a certain level of economic development. (Svensson, 1999; Anwar, and Cooray, 2015; Pham, and Pham, 2019; and Hammani et al., 2020).

\subsection{Economic conditions}

Economic development is a determinant of aid effectiveness to trigger or spur economic and social development, i.e. aid below or above country-specific GDP thresholds are ineffective in order to initiate or stimulate economic growth. Aid fungibility then decreases as a result (Wagner, 2014; Roessler, 2019).

The literature explains that economic development and effective public institutions are required to develop economic activity and provide public goods to the population.

Yet, foreign aid has a beneficial effect on growth rate owing to an increase in public spending and investment; which in turn lead to tax reduction (compensated by an increase in physical capital and better investments) and then an improved economic environment favorable to launching economic development. (Pham, and Pham, 2019). Economic development leads to monetary poverty reduction in aided countries, more than it reduces poverty as measured by the Multidimensional 
Poverty Index (Santos et al., 2019). This phenomenon can be explained across a broad range of policies that require deployment to alleviate poverty as measured through multiple criteria.

However, donors suffer from a bias in their allocation as they preferably allocate their ODA to poorer or more populous countries, contrary to the findings of Kilby, and Dreher (2010). Poorer (in terms of GDP per capita) countries are unable to overcome the "poverty trap".

This purely economic environment is also central in explaining the FDIattractiveness of a country; namely, FDI is channelled to countries where market size measured as the GDP-FDI ratio is more important, and where judicial and business environments are more open to launching or developing new businesses or industries (Hammami et al., 2020).

Contrary to these conclusions, Doucouliagos, and Paldam (2011), and Zardoub, and El Abed (2019) conclude that despite the mainstream assumption that aid contributes to growth, ODA has no statistically significant effect. For Wagner (2014), aid-GDP ratio thresholds define an upper-limit to the absorptive capacity of aid in recipient countries. According to his studies, positive marginal returns of aid to growth are more prevalent in least developed countries, acting as a buffer against external shocks.

\section{Methodology}

\subsection{Data}

To consider the effects that ODA and institutional elements have on HDI improvement, we use data from the World Bank World Development Indicators (WDI), and combine them with the United Nations Development Programme's Human Development Index (UNDP) - that is the only variable coming from a different source than the WDI. As it stands, economics, welfare-related, policyrelated, and other variables are drawn from the WDI.

We restrained our scope of analysis to countries for which HDI, ODA, and official aid data were available and for the time period during which HDI had been calculated.

Eventually our dataset comprises 163 countries over the period 1990-2018. We reckon, however, that some countries lack HDI and other measures, accounted for as "zeros" in our database.

\subsection{Empirical protocol}

We present here our preliminary results using a simple model, testing whether ODA, and official assistance influence the current HDI level. To develop this model, we rely on the following contributions: Roessler (2019), Kanmas and Sarantides (2016), Santos et al. (2019). We also make use of the fruitful contributions and remarks of Alesina and Dollar (2000), Fleck and Kilby (2006) or Hammani et al. (2020). The model equation is presented as follows. 


$$
\begin{aligned}
& H D I_{i, t}=\alpha_{0}+\alpha_{1} G D P_{-} g w t h_{i, t}+\alpha_{2} E x t_{-} d e b t_{i, t}+\alpha_{3} G o v \_e x p d_{i, t}+ \\
& \alpha_{4} \text { Inc_ine }_{i, t}+\alpha_{5} B_{-} \text {dependency } y_{i, t}+\alpha_{6} \text { Health_exp }_{i, t}+\alpha_{7} E_{\text {duc_exp }} \text { ext, }_{1}+ \\
& \alpha_{8} O D A_{-} \text {Assist }_{i, t}+\alpha_{9} F D I_{i, t}+\varepsilon_{i, t}
\end{aligned}
$$

We run OLS and panel regressions on this database with both random and fixed effects.

In a second time, we test an alternative model where gross capital formation and economic openness are taken into account and several variables are modified. Here, we take GNI growth per capita as an explanatory variable instead of GDP per capita to account for all the wealth generated by the residents of a country and any foreign inflow generated by nationals. Our model equation takes the following form:

$$
\begin{aligned}
& H D I_{i, t}=\alpha_{0}+\alpha_{1} \text { GNI_gwth } \text { i,t }_{-}+\alpha_{2} \text { Trade }_{i, t}+\alpha_{3} \text { Poverty }_{i, t}+ \\
& \alpha_{4} B_{-} \text {dependency } y_{i, t}+\alpha_{5} \text { Gov_expd }_{i, t}+\alpha_{6} K_{-} \text {form } \text { for,t }+\alpha_{7} \text { Health_exp } p_{i, t}+ \\
& \alpha_{8} E_{d u c \_\exp _{i, t}}+\alpha_{9} O D A_{-} \text {Assist }_{i, t}+\alpha_{10} \text { FDI }_{i, t}+\alpha_{11} \text { Grants }_{i, t}+\varepsilon_{i, t}
\end{aligned}
$$

\subsection{Variables definition}

Below are presented the independent variables and their definition.

- $\quad$ B_dependency ${ }_{i, t}$ : Government budgetary dependence from institutional foreign donors (Current US\$).

Ratio of the net official development assistance and official aid received over GDP. It represents the non-governmental source of funding available to the government, relative to the country's GDP. If we consider GDP as a rough measure of the revenue of a government, the higher the ratio, the more dependent the recipient country is as well as its government to public foreign aid in order to provide essential goods and services.

$$
\text { - } \quad E d u c_{-} \exp _{i, t}: \quad \text { Government expenditure on education (Current US\$) }
$$

General government expenditure on education (current, capital, and transfers) is expressed as a percentage of total general government expenditure on all sectors (including health, education, social services, etc.). It includes expenditure funded by transfers from international sources to government. General government usually refers to local, regional and central governments.

- $\quad E x t_{-}$debt $_{i, t}$ : External debt stocks (Current US\$ per capita)

Total external debt is debt owed to non-residents repayable in currency, goods, or services. Total external debt is the sum of public, publicly guaranteed, and private non-guaranteed long-term debt, use of IMF credit, and short-term debt. Short-term debt includes all debt having an original maturity of one year or less and interest in arrears on long-term debt.

- $\quad F D I_{i, t}$ : Foreign direct investment, net inflows (Current US\$) 
Foreign direct investment refers to direct investment equity flows in the reporting economy. It is the sum of equity capital, reinvestment of earnings, and other capital. Direct investment is a category of cross-border investment associated with a resident in one economy having control or a significant degree of influence on the management of an enterprise that is resident in another economy. Ownership of 10 percent or more of the ordinary shares of voting stock is the criterion for determining the existence of a direct investment relationship. Data are in current U.S. dollars.

- GDP_gwth $h_{i, t}:$ GDP growth rate per capita (annual \%)

Annual percentage growth rate of GDP per capita based on constant local currency. Aggregates are based on constant 2010 U.S. dollars. GDP per capita is gross domestic product divided by mid-year population. GDP at purchaser's prices is the sum of gross value added by all resident producers in the economy plus any product taxes and minus any subsidies not included in the value of the products. It is calculated without making deductions for depreciation of fabricated assets or for depletion and degradation of natural resources.

- $\quad$ GNI_gwth ${ }_{i, t}$ : GNI per capita growth (Annual \%)

Annual percentage growth rate of GNI per capita based on constant local currency. Aggregates are based on constant 2010 U.S. dollars. GNI per capita is gross national income divided by mid-year population. GNI (formerly GNP) is the sum of value added by all resident producers plus any product taxes (less subsidies) not included in the valuation of output plus net receipts of primary income (compensation of employees, and property income) from abroad.

- Gov_expd $d_{i, t}:$ General government final consumption expenditure (\% of GDP)

General government final consumption expenditure (formerly general government consumption) includes all government current expenditures for purchases of goods and services (including compensation of employees). It also includes most expenditures on national defence and security, but excludes government military expenditures that are part of government capital formation.

- Grants ${ }_{i, t}$ : Grants, and other revenue (\% of revenue)

Grants, and other revenue include grants from other foreign governments, international organizations, and other government units; interest; dividends; rent; requited, nonrepayable receipts for public purposes (such as fines, administrative fees, and entrepreneurial income from government ownership of property); and voluntary, unrequited, nonrepayable receipts other than grants.

- Health_exp $\operatorname{ext}_{i, t}$ : Domestic general government health expenditure per capita (Current US\$) 
Public expenditure on health from domestic sources per capita expressed in current US dollars.

- Inc_ineq $q_{i, t}$ : Income distribution inequality.

Measure of the income inequality as calculated by the ratio between the income share held by lowest $10 \%$ over the income share held by highest $10 \%$; this gives a rough measure of income concentration at the upper end of the income distribution.

- $\quad K_{-}$form $_{\cdot i, t}$ : Gross capital formation (\% of GDP)

Gross capital formation (formerly gross domestic investment) consists of outlays on additions to the fixed assets of the economy plus net changes in the level of inventories. Fixed assets include land improvements (fences, ditches, drains, and so on); plant, machinery, and equipment purchases; and the construction of roads, railways, and the like, including schools, offices, hospitals, private residential dwellings, and commercial and industrial buildings. Inventories are stocks of goods held by firms to meet temporary or unexpected fluctuations in production or sales, and "work in progress." According to the 1993 SNA, net acquisitions of valuables are also considered capital formation.

- ODA_Assist ${ }_{i, t}$ : Net official development assistance and official aid received (Current US\$)

Net official development assistance (ODA) consists of disbursements of loans made on concessional terms (net of repayments of principal) and grants by official agencies of the members of the Development Assistance Committee (DAC), by multilateral institutions, and by non-DAC countries to promote economic development and welfare in countries and territories in the DAC list of ODA recipients. It includes loans with a grant element of at least 25 percent (calculated at a rate of discount of 10 percent). Net official aid refers to aid flows (net of repayments) from official donors to countries and territories in part II of the DAC list of recipients: more advanced countries of Central and Eastern Europe, the countries of the former Soviet Union, and certain advanced developing countries and territories. Official aid is provided under terms and conditions similar to those for ODA. Part II of the DAC List was abolished in 2005. The collection of data on official aid and other resource flows to Part II countries ended with 2004 data. Data are in current U.S. dollars.

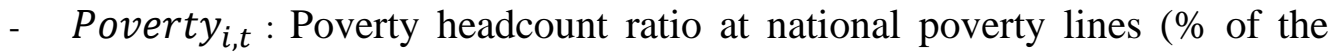
population)

National poverty headcount ratio is the percentage of the population living below the national poverty lines. National estimates are based on population-weighted subgroup estimates from household surveys.

- $\operatorname{Trade}_{i, t}$ : Measure of trade openness (Current US\$)

Ratio of the sum of imports and exports of goods and services over GDP. It reveals to what extent the economy is linked or included in international trade channel 
without considering the actual stage of the value creation.

\section{Results}

Our regression results in Table 1 and Table 2 show that GDP per capita has the largest, and most significant effect on HDI improvement, followed by the reduction of income inequality. Unsurprisingly, education and government expenditures (both insignificant) are positively associated with HDI increases. The result regarding the small marginal effect health expenditures have can be explained through the concentration of healthcare facilities, and their access.

Running panel regression provides us with further insights. Indeed, a decrease in income inequalities has by far the largest effect on HDI improvement, followed by government and education expenditures (now both significant). We can interpret this result as an element corroborating the human capital theory, and theories legitimizing the welfare state. Additionally, this confirms why the HDI indicator was developed in the first place.

Ironically, FDI and ODA as well as assistance only have a minor effect on HDI improvement, and both display a non-significant coefficient at the usual confidence threshold. This supports the strand of literature concluding to overall aid ineffectiveness. 
Table 1: Regression Results from Equation (1) of Independent Variables on HDI

\begin{tabular}{|c|c|c|c|}
\hline $\begin{array}{l}\text { Econometric } \\
\text { method }\end{array}$ & $O L S$ & $\begin{array}{c}\text { Panel with fixed } \\
\text { effects }\end{array}$ & $\begin{array}{c}\text { Panel with } \\
\text { random effects }\end{array}$ \\
\hline$G D P \_g w t h$ & $\begin{array}{c}0,329 * * * \\
(0,088)\end{array}$ & $\begin{array}{l}0,0833 \\
(0,053)\end{array}$ & $\begin{array}{c}0,071 \\
(0,053)\end{array}$ \\
\hline$E x t \_d e b t$ & $\begin{array}{c}0,0000067 * * * \\
(0,0000039)\end{array}$ & $\begin{array}{c}0,0000038 * * * \\
(0,0000033)\end{array}$ & $\begin{array}{c}0,0000038 * * * \\
(0,0000033)\end{array}$ \\
\hline Gov_expd & $\begin{array}{c}0,117 \\
(0,101)\end{array}$ & $\begin{array}{l}0,391 * * * \\
(0,099)\end{array}$ & $\begin{array}{c}0,389 * * * \\
(0,106)\end{array}$ \\
\hline Inc_ineq & $\begin{array}{c}0,203 * * * \\
(0,076) \\
\end{array}$ & $\begin{array}{c}0,537 * * * \\
(0,101) \\
\end{array}$ & $\begin{array}{c}0,513 * * * \\
(0,105)\end{array}$ \\
\hline B_dependendcy & $\begin{array}{c}-0,000026 * * * \\
(0,0000079)\end{array}$ & $\begin{array}{c}0,0000071 \\
(0,0000071)\end{array}$ & $\begin{array}{c}0,000012 \\
(0,0000073)\end{array}$ \\
\hline Health_exp & $\begin{array}{c}0,00025 * * * \\
(0,000013)\end{array}$ & $\begin{array}{c}0,00013 * * * \\
(0,000012)\end{array}$ & $\begin{array}{c}0,00011 * * * \\
(0,000012)\end{array}$ \\
\hline$E d u c \_e x p$ & $\begin{array}{c}0,114 * * \\
(0,045)\end{array}$ & $\begin{array}{c}0,141 * * * \\
(0,030)\end{array}$ & $\begin{array}{c}0,145 * * * \\
(0,030)\end{array}$ \\
\hline ODA_Assist & $\begin{array}{c}0,000058 \\
(0,000021)\end{array}$ & $\begin{array}{c}0,000035 * * \\
(0,000017)\end{array}$ & $\begin{array}{l}0,000032 * \\
(0,000018)\end{array}$ \\
\hline$F D I$ & $\begin{array}{c}-0,000021 * * * \\
(0,0000064)\end{array}$ & $\begin{array}{c}0,0000059 \\
(0,0000052)\end{array}$ & $\begin{array}{c}0,0000063 \\
(0,0000052)\end{array}$ \\
\hline _cons. & $\begin{array}{c}0,57 * * * \\
(0,016)\end{array}$ & $\begin{array}{c}0,453 * * * \\
(0,021)\end{array}$ & $\begin{array}{c}0,52 * * * \\
(0,049)\end{array}$ \\
\hline
\end{tabular}

Independent variables estimates are followed by their standard error in brackets. $* * * \mathrm{p}<0,01 ; * * \mathrm{p}<0,05 ; * \mathrm{p}<0,10$. 
Table 2: Regression Results from Equation (1) of Independent Variables on HDI with robust standard errors

\begin{tabular}{|c|c|c|c|}
\hline $\begin{array}{c}\text { Econometric } \\
\text { method }\end{array}$ & $\begin{array}{c}\text { OLS (robust } \\
\text { standard errors) }\end{array}$ & $\begin{array}{c}\text { Panel with fixed } \\
\text { effects (robust } \\
\text { standard errors) }\end{array}$ & $\begin{array}{c}\text { Panel with random } \\
\text { effects (robust } \\
\text { standard errors) }\end{array}$ \\
\hline GDP_gwth & $\begin{array}{c}0,329 * * * \\
(0,099)\end{array}$ & $\begin{array}{c}0,0833 \\
(0,054)\end{array}$ & $\begin{array}{c}0,071 \\
(0,051)\end{array}$ \\
\hline Ext_debt & $\begin{array}{c}0,0000067 * * * \\
(0,0000031)\end{array}$ & $\begin{array}{c}0,0000038 * * * \\
(0,0000052)\end{array}$ & $\begin{array}{c}0,0000038 * * * \\
(0,0000051)\end{array}$ \\
\hline Gov_expd & $\begin{array}{c}0,117 \\
(0,132)\end{array}$ & $\begin{array}{c}0,391 * * * \\
(0,243)\end{array}$ & $\begin{array}{c}0,389 \\
(0,276)\end{array}$ \\
\hline Inc_ineq & $\begin{array}{c}0,203 * * * \\
(0,062)\end{array}$ & $\begin{array}{c}0,537 * * * \\
(0,163)\end{array}$ & $\begin{array}{c}0,513 * * * \\
(0,187)\end{array}$ \\
\hline B_dependendcy & $\begin{array}{c}-0,000026 * * \\
(0,000012)\end{array}$ & $\begin{array}{c}0,0000071 \\
(0,000010)\end{array}$ & $\begin{array}{c}0,000012 \\
(0,000011)\end{array}$ \\
\hline Health_exp & $\begin{array}{c}0,00025 * * * \\
(0,000012)\end{array}$ & $\begin{array}{c}0,00013 * * * \\
(0,000017)\end{array}$ & $\begin{array}{c}0,00011 * * * \\
(0,000016)\end{array}$ \\
\hline Educ_exp & $0,114 * *$ & $0,141 * * *$ & $0,145 * * *$ \\
$(0,045)$ & $(0,029)$ & $(0,030)$ \\
\hline ODA_Assist & 0,000058 & $0,000035 * *$ & 0,000032 \\
$(0,000028)$ & $(0,000021)$ & $(0,000022)$ \\
\hline FDI & $-0,000021 * * *$ & 0,0000059 & 0,0000063 \\
& $(0,0000041)$ & $(0,0000061)$ & $(0,0000062)$ \\
\hline Independent variables estimates are followed by their standard error in brackets. \\
*cons.
\end{tabular}

Our previous results remain true, for the most part, except for the effect of government expenditures on HDI that is now negative and preponderant in explaining HDI evolution. Likewise, GNI growth benefits HDI, as did GDP growth in our first model (see Table 3 and Table 4).

Additionally, trade or economic openness is positively associated with economic and social progress, as are education expenditures and gross capital formation. This can be considered as a means of supporting liberalization policies, but we must add that ODA, assistance and FDI, whilst being statistically significant, have a marginally insignificant effect in our model. 
Nevertheless, foreign aid grants appear to have a positive effect on HDI in our regressions.

Table 3: Regression Results from Equation (2) of Independent Variables on HDI

\begin{tabular}{|c|c|c|c|}
\hline $\begin{array}{c}\text { Econometric } \\
\text { method }\end{array}$ & $O L S$ & $\begin{array}{l}\text { Panel with fixed } \\
\text { effects }\end{array}$ & $\begin{array}{c}\text { Panel with random } \\
\text { effects }\end{array}$ \\
\hline GNI_gwth & $\begin{array}{c}0,257 * * * \\
(0,062)\end{array}$ & $\begin{array}{c}0,089 * * \\
(0,044)\end{array}$ & $\begin{array}{c}0,082 \\
(0,044) \\
\end{array}$ \\
\hline Trade & $\begin{array}{c}0,096 * * * \\
(0,0059) \\
\end{array}$ & $\begin{array}{c}0,100 * * * \\
(0,0082) \\
\end{array}$ & $\begin{array}{c}0,098 * * * \\
(0,088) \\
\end{array}$ \\
\hline Poverty & $\begin{array}{c}0,112 * * * \\
(0,022)\end{array}$ & $\begin{array}{c}0,078 * * * \\
(0,016) \\
\end{array}$ & $\begin{array}{c}0,079 * * * \\
(0,016) \\
\end{array}$ \\
\hline B_dependency & $\begin{array}{c}-0,000018 * * * \\
(0,000015)\end{array}$ & $\begin{array}{l}-0,000014 \\
(0,000014) \\
\end{array}$ & $\begin{array}{l}-0,0000084 \\
(0,000014) \\
\end{array}$ \\
\hline Govexp & $\begin{array}{l}-0,059 \\
(0,049)\end{array}$ & $\begin{array}{c}-0,161 * * * \\
(0,054)\end{array}$ & $\begin{array}{c}-0,18 * * * \\
(0,056)\end{array}$ \\
\hline Kform & $\begin{array}{l}0,057 * \\
(0,034)\end{array}$ & $\begin{array}{c}0,077 * * * \\
(0,031)\end{array}$ & $\begin{array}{c}0,083 * * * \\
(0,031)\end{array}$ \\
\hline Healthexp & $\begin{array}{l}0,0033 * * * \\
(0,000012)\end{array}$ & $\begin{array}{c}0,00015 * * * \\
(0,000011) \\
\end{array}$ & $\begin{array}{c}0,00013 * * * \\
(0,000011) \\
\end{array}$ \\
\hline Educexp & $\begin{array}{c}0,094 * * * \\
(0,034)\end{array}$ & $\begin{array}{c}0,133 * * * \\
(0,027) \\
\end{array}$ & $\begin{array}{c}0,138 * * * \\
(0,027)\end{array}$ \\
\hline ODAAssist & $\begin{array}{c}0,000043 * * * \\
(0,000042) \\
\end{array}$ & $\begin{array}{c}0,000045 * * * \\
(0,000038) \\
\end{array}$ & $\begin{array}{c}0,000047 * * * \\
(0,000038) \\
\end{array}$ \\
\hline FDInet & $\begin{array}{c}0,0000069 * * * \\
(0,0000042)\end{array}$ & $\begin{array}{c}0,000014 * * * \\
(0,0000041) \\
\end{array}$ & $\begin{array}{c}0,000014 * * * \\
(0,0000042) \\
\end{array}$ \\
\hline Grants & $\begin{array}{c}0,045 * * * \\
(0,016) \\
\end{array}$ & $\begin{array}{c}0,082 * * * \\
(0,015) \\
\end{array}$ & $\begin{array}{c}0,085 * * * \\
(0,015) \\
\end{array}$ \\
\hline _cons & $\begin{array}{c}0,439 * * * \\
(0,012) \\
\end{array}$ & $\begin{array}{c}0,454 * * * \\
(0,016) \\
\end{array}$ & $\begin{array}{c}0,463 * * * \\
(0,013) \\
\end{array}$ \\
\hline \multicolumn{4}{|c|}{$\begin{array}{l}\text { Independent variables estimates are followed by their standard error in brackets. } \\
* * * \mathrm{p}<0,01 ; * * \mathrm{p}<0,05 ; * \mathrm{p}<0,10 \text {. }\end{array}$} \\
\hline
\end{tabular}

Hence, below or above a certain level of economic attainment, aid is ineffective and FDI should be subject to specific sectoral development strategies ex ante to reap its benefits in the recipient country's economy.

Paradoxically, we find poverty headcount to be positively associated with HDI improvement. This could be the result of a concentration of wealth or income at the 
top of the income distribution: growth benefits the richest and the poorest are left behind.

Government reliance on foreign sources of income strongly influences HDI, but the coefficients remain statistically insignificant.

Table 4: Regression Results from Equation (2) of Independent Variables on HDI with robust standard errors

\begin{tabular}{|c|c|c|c|}
\hline $\begin{array}{l}\text { Econometric } \\
\text { method }\end{array}$ & $\begin{array}{c}\text { OLS (robust } \\
\text { standard errors) }\end{array}$ & $\begin{array}{l}\text { Panel with fixed } \\
\text { effects (robust } \\
\text { standard errors) } \\
\end{array}$ & $\begin{array}{c}\text { Panel with random } \\
\text { effects (robust } \\
\text { standard errors) }\end{array}$ \\
\hline GNI_gwth & $\begin{array}{c}0,257 * * * \\
(0,071)\end{array}$ & $\begin{array}{c}0,089 \\
(0,066)\end{array}$ & $\begin{array}{c}0,082 \\
(0,066)\end{array}$ \\
\hline Trade & $\begin{array}{c}0,096 * * * \\
(0,0058) \\
\end{array}$ & $\begin{array}{c}0,100 * * * \\
(0,035) \\
\end{array}$ & $\begin{array}{c}0,098 * * \\
(0,041) \\
\end{array}$ \\
\hline Poverty & $\begin{array}{c}0,112 * * * \\
(0,018)\end{array}$ & $\begin{array}{c}0,078 * * * * \\
(0,022) \\
\end{array}$ & $\begin{array}{c}0,079 * * * \\
(0,022) \\
\end{array}$ \\
\hline B_dependency & $\begin{array}{c}-0,000018 * * * \\
(0,000017) \\
\end{array}$ & $\begin{array}{c}-0,000014 \\
(0,0000085) \\
\end{array}$ & $\begin{array}{r}-0,0000084 \\
(0,0000092) \\
\end{array}$ \\
\hline Govexp & $\begin{array}{l}-0,059 \\
(0,069)\end{array}$ & $\begin{array}{c}-0,161 * * * \\
(0,181)\end{array}$ & $\begin{array}{c}-0,18 \\
(0,190)\end{array}$ \\
\hline Kform & $\begin{array}{c}0,057 \\
(0,043)\end{array}$ & $\begin{array}{c}0,077 * * * \\
(0,099) \\
\end{array}$ & $\begin{array}{c}0,083 \\
(0,102) \\
\end{array}$ \\
\hline Healthexp & $\begin{array}{l}0,0033 * * * \\
(0,000011)\end{array}$ & $\begin{array}{c}0,00015 * * * \\
(0,000038)\end{array}$ & $\begin{array}{c}0,00013 * * * \\
(0,000039) \\
\end{array}$ \\
\hline Educexp & $\begin{array}{c}0,094 * * * \\
(0,033)\end{array}$ & $\begin{array}{c}0,133 * * * \\
(0,049) \\
\end{array}$ & $\begin{array}{c}0,138 * * * \\
(0,051) \\
\end{array}$ \\
\hline ODAAssist & $\begin{array}{c}0,000043 * * * \\
(0,000042) \\
\end{array}$ & $\begin{array}{c}0,000045 * * * \\
(0,000035) \\
\end{array}$ & $\begin{array}{c}0,000047 \\
(0,000039) \\
\end{array}$ \\
\hline FDInet & $\begin{array}{c}0,0000069 * * * \\
(0,0000031)\end{array}$ & $\begin{array}{c}0,000014 * * * \\
(0,0000071)\end{array}$ & $\begin{array}{c}0,000014 * \\
(0,0000079) \\
\end{array}$ \\
\hline Grants & $\begin{array}{c}0,045 * * * \\
(0,016)\end{array}$ & $\begin{array}{c}0,082 * * * \\
(0,037) \\
\end{array}$ & $\begin{array}{c}0,085 * * \\
(0,038) \\
\end{array}$ \\
\hline _cons & $\begin{array}{c}0,439 * * * \\
(0,015)\end{array}$ & $\begin{array}{c}0,454 * * * \\
(0,044)\end{array}$ & $\begin{array}{c}0,463 * * * \\
(0,046)\end{array}$ \\
\hline
\end{tabular}




\section{Conclusion}

In this paper, we develop a model aimed at capturing policy decision and external budget components which could explain HDI improvement. We find ODA, assistance, and FDI are not explanatory of the HDI level, whilst expenditures in education and general government expenditures display the largest effects on HDI improvement.

Economic growth and integration in international value chains also seem to render benefits to the recipient country, parallel to Alesina and Dollar's conclusion (2000). In accordance with the literature on this topic, our R-squared ranges from $25 \%$ to almost $40 \%$. We find comparable results regarding aid effectiveness.

Drawing on this, we consider using new indicators such as alternative measures of budgetary dependency, for instance, the ratio of ODA and assistance on government expenditures. Moreover, institutional variables such as levels of corruption or democracy as well as other variables used by Roessler (2019), which may prove relevant in future analysis.

Analogically, we relate to Kanmas and Sarantides inasmuch as some targeted expenditures are required to improve social condition, such as gross capital formation as shown in our model (2016). This supports Santos et al. who call for studying poverty reduction from a multidimensional perspective (2019).

As our model shows, economic growth, reduction in income distribution as well as government and public sector investments are required to improve people's living conditions.

Our preliminary results lead us to be somewhat cautious, but our findings suggest a daring conclusion, i.e. internal decisions, especially budgetary allocation matter more in terms of enhancing economic and social outcomes rather than opting for targeted foreign financial flows. 


\section{References}

[1] Alesina, A., and Dollar, D. (2000), "Who Gives Foreign Aid to Whom, and Why?", Journal of Economic Growth, Vol. 5 (March 2000), pp. 33-63

[2] Alesina, A., and Weder, B. (2002), "Do corrupt governments receive less foreign aid?", American Economic Review, Volume 92 (4), pp. 1126-1137

[3] Anwar, S., and Cooray, A. (2015), "Financial flows, and per capita income in developing countries", International Review of Economics, and Finance, Volume 35, pp. 304-314

[4] Chauvet, L., and Mesplé-Somps, S. (2007), "Impact des financements internationaux sur les inégalités des pays en développement", Revue Economique, Volume 58 (3), pp. 735-744

[5] Doucouliagos, H., and Paldam, M. (2011), "The Ineffectiveness of Development Aid on Growth: An Update European”, Journal of Political Economy, Volume 27, pp. 399-404

[6] Dreher, A. Fuchs, A., Hodler, R., Parks, B. C., Raschky, P. A., and Tierney, M. J. (2019), "African leaders, and the geography of China's foreign assistance", Journal of Development Economics, Volume 140, pp. 44-71

[7] Fleck, R. K., and Kilby, C. (2006), "How do Political changes influence US bilateral Aid Allocations? Evidence from Panel data", Review of Development Economics, Volume 10 (2), pp. 210-223

[8] Hammami, H., Hammami, M., Coulibaly, S., and Marzouk, M. (2020), "Determinants of FDI attractiveness: A MCI model approach", Economics Bulletin, Volume 40 (Issue 2), pp. 1033-1048

[9] Kanmas, P., and Sarantides, V. (2016), "Fiscal Redistribution around Elections when Democracy is not "The Only Game in Town", Public Choice, Volume 168, pp. 279-311

[10] Kilby, C. and Dreher, A. (2010), “The impact of aid on growth revisited: Do donor motives matter?", Economics Letters, Volume 107, pp. 338-340

[11] Lessmann, C., and Markwardt, G. (2016), "Aid, growth, and devolution: Considering aid modality, and different types of decentralisation", World Development, Volume 84 (August 2016), pp. 118-130

[12] Pham, N.-S. and Pham, T. K. C. (2019), "Foreign aid, recipient government's fiscal behavior, and economic growth", Economics Bulletin, Volume 39 (Issue 4), pp. 2457-2466

[13] Prakash, N., Rockmore, M. and Uppal, Y. (2019), "Do Criminally Accused Politicians Affect Economic Outcomes? Evidence from India”, Journal of Development Economics, Volume 141, 102370

[14] Roessler, M. (2019), "Political Regimes, and Publicly Provided Goods, Why Democracy Needs Development”, Public Choice, Volume 180, pp. 301-331

[15] Santos, M. E., Dabus, C., and Delbianco, F. (2019), "Growth, and poverty revisited from a multidimensional perspective", Journal of Development Studies, Volume 55 (Issue 2), pp. 260-2277 
[16] Strange, A. M., Dreher, A., Fuchs, A., Parks, B., and Tierney, M.J. (2017), "Tracking under-reported financial flows: China's development finance, and the aid-conflict nexus revisited", Journal of Conflict Resolution, Volume 61 (5), pp. $935-963$

[17] Svensson, J. (1999), "When is the foreign aid policy credible? Aid dependence, and conditionality", Journal of Development Economics, Vol. 61, pp. 61-84

[18] Tezanos, S., Quiñones, A., and Guijarro, M. (2013), "Inequality, aid, and growth: Macroeconomic impact of aid grants, and loans in Latin America, and the Caribbean", Journal of Applied Economics, Volume 16 (1), pp. 153-177

[19] Wagner, L. (2014), "Identifying thresholds in aid effectiveness", Review of World Economics/Weltwirtschaftliches Archiv, Volume 150 (No. 3), pp. 619-638

[20] Zardoub, A., and El Abed, R. (2019), "Short-, and Long-Term Effects of Financial Flows on Economic Growth", Journal of Economic Integration, Vol. 34 (No.4 - December 2019), pp. 705-724 